\title{
STUDY OF ARTERIAL SUPPLY OF CAECUM AND APPENDIX: A
} CADAVERIC STUDY

\section{Ashwini Balasaheb Nuchhi *1, Sandhya Vikas Yatagiri ${ }^{2}$, B G Patil ${ }^{3}$, B M Bannur ${ }^{4}$}

${ }^{*_{1,2}}$ Assistant Professor, Department of Anatomy, BLDEU's Shri B M Patil Medical College, Hospital Research centre, Vijayapura, Karnataka, India.

${ }^{3}$ Professor, Department of Anatomy, BLDEU's Shri B M Patil Medical College, Hospital Research centre, Vijayapura, Karnataka, India.

${ }^{4}$ Professor and Head, Department of Anatomy, BLDEU's Shri B M Patil Medical College, Hospital Research centre, Vijayapura, Karnataka, India.

\section{ABSTRACT}

Background: A precise knowledge of vascular anatomy of caecum and vermiform appendix is a must while doing surgical procedures like right hemicolectomy, appendicectomy and reconstructive microsurgeries using appendix. The aim is to study the arterial supply of the caecum and vermiform appendix, the findings of which may reveal more anatomical details including variations.

Materials and Methods: 25 specimens of caecum and appendix with their arteries intact were dissected, removed from cadavers and preserved, the ileocolic artery and its branches to the caecum and vermiform appendix were traced carefully, painted with red acrylic paint and observations recorded.

Results: The common caecal artery was seen in $52 \%$ of specimens. The common caecal artery which gave rise to anterior caecal artery in $40 \%$ and posterior caecal artery in $36 \%$ of specimens was the most common source of origin of these two arteries. The commonest source of origin of main appendicular artery was ileocolic artery in $28 \%$. In $40 \%$ of specimens appendix received more than one appendicular artery. Arterial arcades were present in 12 specimens (48\%) mainly between superior and inferior divisions of ileocolic artery.

Conclusion: From this study we conclude that the anatomical details such as the origin, number of arteries and pattern of branching of the caecal and appendicular arteries are not only important for ablative surgeries but also in reconstructive microsurgeries using appendix for the survival of graft.

KEY WORDS: arteries, caecum, appendix.

Address for Correspondence: Dr. Ashwini Balasaheb Nuchhi, Assistant professor Department of Anatomy BLDEU's Shri B M Patil Medical College, Hospital Research centre, Vijayapura-03. Karnataka, India. Mobile no 9986361044 E-Mail: ashnuchhi@gmail.com

\section{Access this Article online}

\section{Quick Response code}

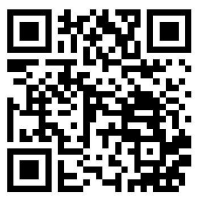

DOI: $10.16965 /$ ijar.2017.272

Web site: International Journal of Anatomy and Research ISSN 2321-4287

www.ijmhr.org/ijar.htm

Received: 26 May 2017

Peer Review: 27 May 2017

Revised: None
Accepted: $10 \mathrm{Jul} 2017$

Published (O): $31 \mathrm{Jul} 2017$

Published (P): 31 Jul 2017

\section{INTRODUCTION}

Variation is the law of nature. Every human being is unique to such an extent that even identical twins are not exactly the same. Some of the variations are of considerable clinical significance such as vascular ones. Vascular variationsare common and clinically significant which create a challenge to the anatomists and surgeons.

The lleocolic artery, lowest branch of the superior mesenteric artery divides into superior and inferior branches. The inferior branch divides 
into- ascending colic branch, anterior caecal branch supplying the anterior surface of the caecum, posterior caecal branch supplying the posterior surface of the caecum, appendicular artery supplying the appendix and ileal branch supplying terminal part of ileum [1].

The main appendicular artery is defined as the one which runs in the cresentic fold of the mesoappendix to the tip of appendix giving numerous branches which supply whole length of appendix including its tip. The terminal part of the artery lies on the wall of the appendix and may be thrombosed in appendicitis, which results in distal gangrene or necrosis. Accessory appendicular artery is the one which supplies other parts of the appendix except the tip. These are common and many individuals possess two or more arteries of supply [2].

Caeco-appendicular artery supplies base of appendix and caecal bottom [3]. The caecum and appendix carries great surgical significance as they are affected by many pathological conditions such as appendicitis, ileocaecal tuberculosis, carcinomas, isolated caecal infarction, angiodysplasias, varices and many more. Therefore a clear understanding of the arterial supply of the caecum and appendix is a must for the surgeons while performing procedures like appendicectomy[4], mesenteric lengthening in case of pouch anal anastomosis [5], therapeutic embolisation in case of hemorrhage [6] and for laparoscopic surgeries [7].

The vascularised appendix has been used on its pedicle and subsequently in free transplant with success to rebuild urethra, ureters, the uterine tubes and extra hepatic biliary tracts. The precise knowledge of arterial supply of appendix is not only important for ablation of the appendix but also for various reconstructive microsurgeries using appendix to assure the survival of whole of the transplant. At least two vessels are required to ensure the whole of its vascularisation [8].

Superior mesenteric angiogram or ileocolic angiogram helps to diagnose carcinoma of caecum in situations where the routine investigations like barium enema and colonoscopy have missed the diagnosis and are also helpful in diagnosing angiodysplasia of Caecum [9]. Hence this work has been done to study the arterial supply of the caecum and vermiform appendix, to determine the origin, number of arteries and pattern of branching.

\section{MATERIALS AND METHODS}

The study of arterial supply of caecum and appendix was conducted on 25 specimens of caecum and appendix with their arteries intact. The specimens were obtained from cadavers of Department of Anatomy, BLDEU's Shri B M Patil Medical College, Hospital and Research centre. Vijayapur, Karnataka.

Method of data collection: Sample size: It was expected to consider 25 specimens of caecum and appendix with intact arteries.

With proportion of variations of appendicular artery $80 \%$ [2], 20\% allowable error and 95\% confidence limit using the statistical formula $n=(1.96)^{2} \mathrm{p} \mathrm{q} / \mathrm{L}^{2}$. Where $\mathrm{n}=$ sample size, $p=$ Proportion of variations of appendicular artery $=80 \%, q=100-p L=$ allowable error $=20 \%$.

Methodology: The specimens of caecum, appendix, part of ascending colon, terminal part of ileum and part of superior mesenteric artery with ileocolic artery were separated from the surrounding structures after noting relation of ileocolic artery and its branches. Then two ligatures were applied, one on the ascending colon $20 \mathrm{cms}$ from the ileocaecal junction and another one on the terminal ileum, $5 \mathrm{cms}$ from the ileocaecal junction. The appendix and caecum were removed en mass along with arteries. The collected specimens were preserved in $5 \%$ formalin and then specimens were dissected, cleaned and numbered. The ileocolic artery and its branches- the anterior caecal, posterior caecal and appendicular arteries were traced and painted with red acrylic paint in order to make them bold and photographs were taken. The observations were recorded with regard to number, origin and branching pattern of caecal, appendicular arteries.

\section{Statistical analysis:}

Data was analysed using the following statistical methods:

1) Mean +/_standard deviation

2) Percentages 
Fig. 1: Specimens of caecum and appendix with branches of ileocolic artery.

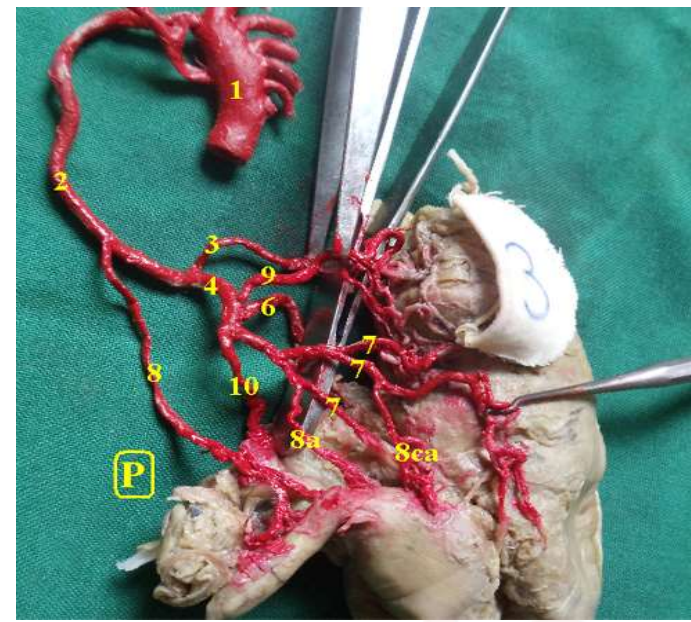

Fig. 3: Specimens of caecum and appendix with branches of ileocolic artery.

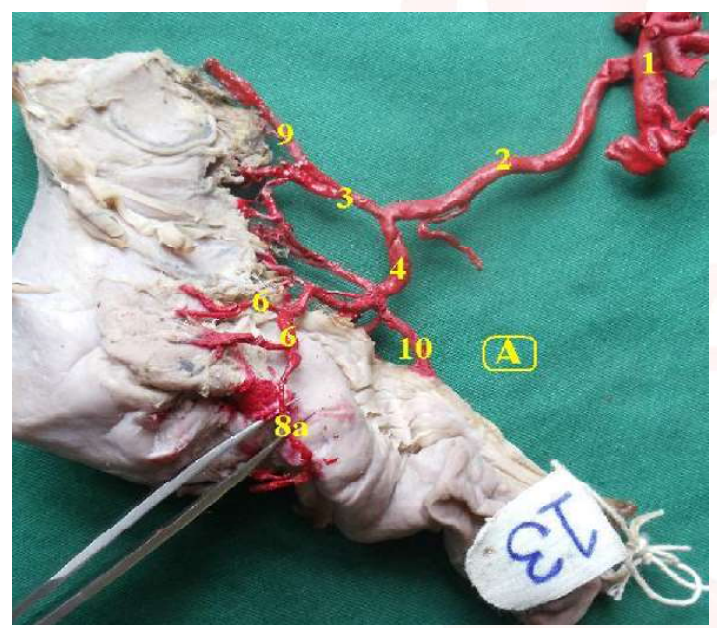

Fig.2: Specimens of caecum and appendix with branches of ileocolic artery.

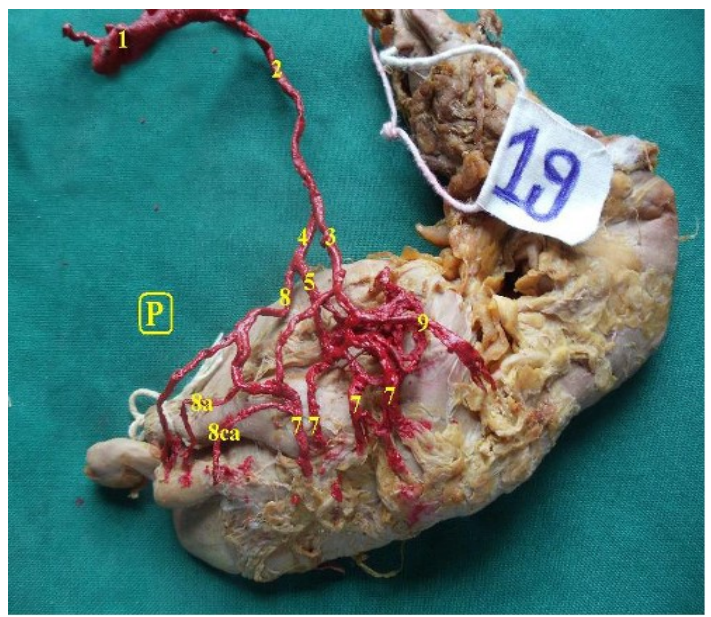

Fig.4: Specimens of caecum and appendix with branches of ileocolic artery.

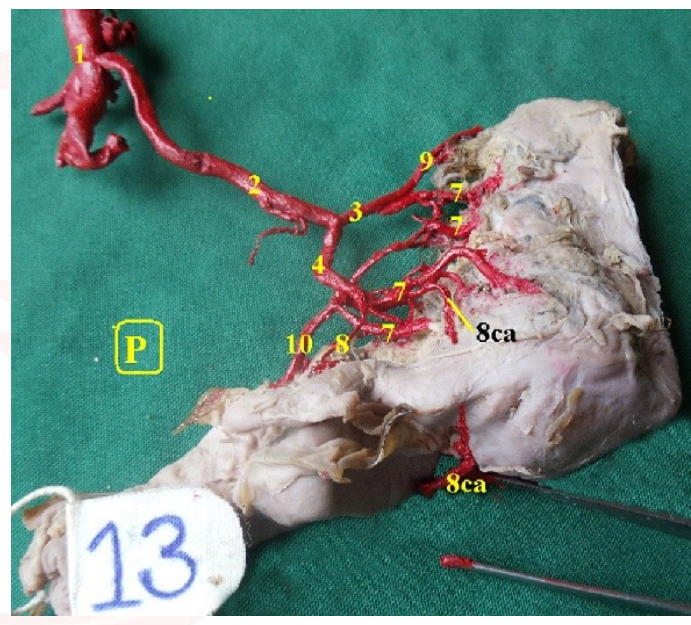

1 - Superior mesenteric artery,2 - Ileocolic artery,3 - Superior division of Ileocolic artery,4 - Inferior division of Ileocolic artery,5 - Common caecal artery,6 - Anterior caecal artery,7 - Posterior caecal artery,8 - Main Appendicular artery,8a -Accessory Appendicular artery,8ca - Caeco-appendicular artery, 9 - Ascending colic artery,10- Ileal branch,11- Right colic artery, A - Anterior view, P - Posterior view.

\section{RESULTS}

In the present study 25 specimens were studied for the arteries supplying caecum and vermiform appendix.

Arterial arcades were present in 12 specimens $(48 \%)$ as seen in Fig- 3 , out of 12 specimens arterial arcades were present between superior and inferior divisions of ileocolic artery in 5 specimens (42\%), between two branches of common caecal artery in 3 specimens ( $25 \%)$, between main appendicular artery and posterior caecal artery in 1 specimen (8.3\%), between common caecal artery and ascending colic artery in 1 specimen (8.3\%), in 1 specimen (8.3\%) two arcades were present one between common caecal artery and ascending colic artery another between ascending colic artery and main appendicular artery, in one more specimen(8.3\%) two arcades were present one between superior and inferior divisions another between two branches of common caecal artery. Table 1: ORIGIN OF COMMON CAECAL ARTERY which was present only in 13 specimens (52\%), as seen in Fig-2.

\begin{tabular}{|l|c|c|}
\hline \multicolumn{1}{|c|}{ Source } & Specimens & Percentage \\
\hline 1) Inferior division & 6 & 46.2 \\
\hline 2) Ileocolic artery & 4 & 30.7 \\
\hline $\begin{array}{l}\text { 3) Arterial arcade between superior } \\
\text { and inferior divisions }\end{array}$ & 2 & 15.4 \\
\hline 4) Superior division & 1 & 7.7 \\
\hline
\end{tabular}

Table 2: origin of anterior caecal artery.

\begin{tabular}{|l|c|c|}
\hline \multicolumn{1}{|c|}{ Source } & Specimens & Percentage \\
\hline 1)Common caecal artery & 10 & 40 \\
\hline 2) Superior division & 5 & 20 \\
\hline 3) Arterial arcade & 5 & 20 \\
\hline 4) Inferior division & 2 & 8 \\
\hline 5) Ileocolic artery & 2 & 8 \\
\hline 6) Inferior division and common caecal & 1 & 4 \\
\hline
\end{tabular}


In the present study out of 25 specimens 18 specimens had single anterior caecal artery and 7 specimens had 2 anterior caecal arteries.

Table 3: Origin of posterior caecal artery.

\begin{tabular}{|l|c|c|}
\hline \multicolumn{1}{|c|}{ Source } & Specimens & Percentage \\
\hline 1) Common caecal artery & 9 & 36 \\
\hline 2) Arterial arcade & 7 & 28 \\
\hline 3) Superior division & 4 & 16 \\
\hline 4) Inferior division & 2 & 8 \\
\hline 5) Ileocolic artery & 1 & 4 \\
\hline 6) Inferior division and common caecal & 1 & 4 \\
\hline 7) common caecal and arterial arcade & 1 & 4 \\
\hline
\end{tabular}

In the present study out of 25 specimens- 6 specimens $(24 \%)$ had single posterior caecal artery, 5 specimens (20\%) had 2 posterior caecal arteries, 8 specimens (32\%) had 3 posterior caecal arteries and 6 specimens $(24 \%)$ had 4 posterior caecal arteries

Table 4: Origin of main appendicular artery.

\begin{tabular}{|l|c|c|}
\hline \multicolumn{1}{|c|}{ Source } & Specimens & Percentage \\
\hline 1) Ileocolic artery & 7 & 28 \\
\hline 2) Arterial arcade & 5 & 20 \\
\hline 3) Inferior division & 5 & 20 \\
\hline 4)Posterior caecal artery & 4 & 16 \\
\hline 5)Common caecal artery & 3 & 12 \\
\hline 6) Superior division & 1 & 4 \\
\hline
\end{tabular}

Table 5: Origin of accessory appendicular artery.

\begin{tabular}{|l|c|c|}
\hline \multicolumn{1}{|c|}{ Source } & Specimens & Percentage \\
\hline 1) Ileal branch & 2 & 29 \\
\hline 2) Arterial arcade & 2 & 29 \\
\hline 3) Inferior division & 1 & 14 \\
\hline 4) Common caecal artery & 1 & 14 \\
\hline 5) Posterior caecal artery & 1 & 14 \\
\hline
\end{tabular}

Table 6: Origin of caeco-appendicular artery.

\begin{tabular}{|c|c|c|}
\hline Source & Specimens & Percentage \\
\hline 1) Posterior caecal artery & 4 & 80 \\
\hline 2) Anterior and Posterior caecal artery & 1 & 20 \\
\hline
\end{tabular}

The appendix was supplied by single appendicular artery in 15 specimens (60\%) and in 10 specimens (40\%) it had received more than one appendicular artery, among those 7 specimens (28\%) had 2 arteries, 3 specimens (12\%) had 3 arteries as seen in Fig-1,2\&4.

\section{DISCUSSION}

The knowledge of arterial pattern of caecum and appendix is essential for surgeons and radiologists as it helps to predefine the abnormality by invasive and non invasive studies. Therefore anatomy of these arteries is an increasingly essential component for many therapeutic and surgical procedures.

Table 7: Comparison of presence of common caecal artery and origin of anterior and posterior caecal arteries with previous studies.

\begin{tabular}{|c|c|c|c|c|c|}
\hline \multirow{2}{*}{ Author } & \multirow{2}{*}{$\begin{array}{c}\text { presence of } \\
\text { common caecal } \\
\text { artery }\end{array}$} & \multicolumn{2}{|c|}{ Origin of anterior caecal artery } & \multicolumn{2}{|c|}{ Origin of posterior caecal artery } \\
\hline & & $\begin{array}{l}\text { From common } \\
\text { caecal artery }\end{array}$ & $\begin{array}{l}\text { Different } \\
\text { origins }\end{array}$ & $\begin{array}{l}\text { From common } \\
\text { caecal artery }\end{array}$ & $\begin{array}{c}\text { Different } \\
\text { origins }\end{array}$ \\
\hline Michel et al (1963)|[10] & $36 \%$ & $36 \%$ & $64 \%$ & $36 \%$ & $64 \%$ \\
\hline Ures et al (1979)[11] & $76.20 \%$ & $76.20 \%$ & $23.70 \%$ & $76.20 \%$ & $23.70 \%$ \\
\hline Vandamme et al (1982)[3] & $53 \%$ & $53 \%$ & $47 \%$ & $53 \%$ & $47 \%$ \\
\hline Present study & $52 \%$ & $40 \%$ & $60 \%$ & $36 \%$ & $64 \%$ \\
\hline
\end{tabular}

The results of present study are in accordance with study done by Vandamme etal(1982)[3] .

Table 8: Comparison of no. of appendicular arteries whether single or more than one with previous studies.

\begin{tabular}{|l|c|c|}
\hline \multicolumn{1}{|c|}{ Authors } & $\begin{array}{c}\text { Single appendicular } \\
\text { artery }\end{array}$ & $\begin{array}{c}\text { More than one } \\
\text { appendicular artery }\end{array}$ \\
\hline Shah et al (1964)[12] & $70 \%$ & $30 \%$ \\
\hline Solanke et al(1968)[2] & $20 \%$ & $80 \%$ \\
\hline Katzarski et al(1979)[13] & $60.20 \%$ & $39.80 \%$ \\
\hline Vandamme(1982)[3] & $94 \%$ & $6 \%$ \\
\hline Ajmani(1983)[14] & $61 \%$ & $39 \%$ \\
\hline Ouattara(2007)[8] & $24 \%$ & $76 \%$ \\
\hline Present study & $60 \%$ & $40 \%$ \\
\hline
\end{tabular}

The results of present study are in accordance with study done by Katzarski (1979), Ajmani(1983).

Table 9: Comparison of origin of main appendicular arteries from different sources with previous studies.

\begin{tabular}{|c|c|c|c|c|c|}
\hline Author & $\begin{array}{c}\text { Ileocolic } \\
\text { artery }\end{array}$ & $\begin{array}{c}\text { Inferior } \\
\text { division }\end{array}$ & $\begin{array}{c}\text { Superior } \\
\text { division }\end{array}$ & $\begin{array}{c}\text { Arterial } \\
\text { arcade }\end{array}$ & $\begin{array}{c}\text { Posterior caecal } \\
\text { artery }\end{array}$ \\
\hline Solanke(1968)[2] & $50 \%$ & $32 \%$ & $3 \%$ & $1 \%$ & - \\
\hline Vandamme (1982)[3] & $58 \%$ & $26 \%$ & & & $15 \%$ \\
\hline Outtara(2007)[8] & $35 \%$ & $4.25 \%$ & - & 1 & $13 \%$ \\
\hline Present study & $28 \%$ & $20 \%$ & $1 \%$ & $20 \%$ & $16 \%$ \\
\hline
\end{tabular}

It indicates ileocolic artery is the most common source of origin of main appendicular artery as compared with previous studies.

Vandamme et al [3] found caecoappendicular artery in $65 \%$ of cases, Outtara [8] in 32\% cases and in present study $4 \%$ of cases.

\section{CONCLUSION}

Better anatomical knowledge about the caecal and appendicular arteries and their variations is essential for surgeons while operating on the ileocolic region for treating many pathological conditions and also in treating congenital anomalies. The details of origin, number and 
branching pattern of appendicular arteries help the surgeons to use the appendix with its pedicle or as free transplant in many reconstructive microsurgeries. The same knowledge is also helpful in the interpretation of superior mesenteric or ileocolic angiograms by radiologists. Work done in the present study was just like exploring the tip of an iceberg. The rest of it needs to be explored.

\section{Conflicts of Interests: None}

\section{REFERENCES}

[1]. Standring S. Large intestine. In: Borley NR. Gray's Anatomy-The Anatomical basis of clinical practice. $40^{\text {th }}$ Edn. Edinburgh: Churchill Livingstone; 2008:1141-5.

[2]. Solanke TF. The blood supply of vermiform appendix in Nigerians. J. Ant. 1968;102:353-61.

[3]. Vandamme JPJ, Bonte JA. New look at the blood supply of ileocolic angle. Acta Anat. 1982;113:1-14.

[4]. Neil J, Mortensen MC, Oliver J. The small and large intestines. In: Russel RCG, Norman SW, Christopher, Bulstrode JK. Bailey and Love's short practice of Surgery. 24 ${ }^{\text {th }}$ Edn. London: Arnold Publications; 2004:1153-86

[5]. Martel P, Blanc P, Bothereau H, Malafosse M, Gallot D. Comparative anatomical study of division of the ileocolic pedicle or the superior mesenteric pedicle for mesenteric lengthening. British Journal of Surgery 2002;89:775-8.

[6]. Gerlock AJ, Muhletaler CA, Berger JL, Halter SA, O'Leary $J P$, Avant GR. Infarction after embolization of the ileocolic artery. Cardiovascular Interventional Radiology 1981;4:202-5.
[7]. Zucker KA. Laparoscopic appendicectomy. In: Josloff RK, Zucker KA. Surgical laparoscopy. $2^{\text {nd }}$ Edn.Philadelphia: Lippincott Williams and Wilkins; 2001: 231-2.7.

[8]. Ouattara D, Kipre YZ, Broalet E, Seri FG, Angate HY, Bi N'Guessan GG. Classification of the terminal arterial vascularization of the appendix with a view to its use in reconstructive microsurgery. Surg Radiol Anat 2007;29:635-41.

[9]. Ho S, Jackson J. The Angiographic Diagnosis of CoIonic Carcinoma. Clinical Radiology 1998;53:3459.

[10]. Michels NA, Siddharth P, Kornblith PL, Parke WW. The variant blood supply to the small and large intestines, its importance in regional resections. A new anatomic study based on $\mathbf{4 0 0}$ dissections with complete review of literature. J Int.Coll Surgeons 1963;39:127-8.

[11]. Ures J, Stacchini A, Prates JC, Gatto IM, Ures S. Angiographic anatomy of the caecal artery. Arq Gastroenterol. 1979;16:8-11.

[12]. Shah MA, Shah M. The arterial supply of the appendix. Anatomical Record. 1964;95:457-60.

[13]. Katzarski M, Gopal Rao VK, Brady K. Blood Supply and position of the vermiform appendix in Zambians. Med J Zambia 1979;13:32-4.

[14]. Ajmani ML, Ajmani K. The position, length and arterial supply of vermiform appendix. Anat Anz 1983;153:369-74.

How to cite this article:

Ashwini Balasaheb Nuchhi, Sandhya Vikas Yatagiri, B G Patil, B

$M$ Bannur. STUDY OF ARTERIAL SUPPLY OF CAECUM AND

APPENDIX: A CADAVERIC STUDY. Int J Anat Res 2017;5(3.1):4158-

4162. DOI: $10.16965 /$ ijar.2017.272 